\title{
Colonização, transformações do território e conflitos rurais em Barbosa Ferraz, PR, Brasil
}

\author{
Colonization, territorial transformations and rural conflicts in \\ Barbosa Ferraz, PR, Brazil
}

\section{Colonización, transformaciones del territorio y conflictos rurales en Barbosa Ferraz, PR, Brasil}

\author{
Aline Jorge \\ https:// orcid.org./0000-0001-6867-3162 \\ albuquerquealine312@gmail.com \\ Universidade Estadual de Maringá, UEM, Maringá, PR \\ Elpídio Serra \\ https:/ / orcid.org./0000-0002-1586-2370 \\ serraelpidio@gmail.com \\ Universidade Estadual de Maringá, UEM, Maringá, PR
}

\begin{abstract}
Resumo: os conflitos rurais atuais no Brasil resultam de um processo histórico de desterritorialização e de exclusão, intensificado pelo avanço do capitalismo sobre a agricultura. Movimentos socioterritoriais, caso do movimento MST, desafiam o poder hegemônico e contestam a legalidade da propriedade capitalista, mobilizando camponeses a ocupar terras que não cumprem a função social, transformando-as em territórios de reforma agrária no Paraná. Neste artigo, sustentado em dados de campo e em referenciais bibliográficos, pretende estudar a colonização, as transformações do território e os conflitos rurais, tendo como referência o município de Barbosa Ferraz, na Mesorregião Centro-Ocidental do estado do Paraná.
\end{abstract}

Palavras-chave: Luta pela terra, Reforma agrária, Ocupações de terra.

Abstract: the current rural conflicts are the result of a historical process of deterritorialization and exclusion, intensified from the advance of capitalism over agriculture. Socio-territorial movements, such as the MST movement, challenge hegemonic power and contest the legality of capitalist property, mobilizing peasants to occupy lands that do not carry out their social function, transforming them into agrarian reform territories in Paraná. This paper, supported by field data and bibliographical references, aims to study the colonization, territorial transformations and rural conflicts, taking as reference the municipality of Barbosa Ferraz, in the Paraná State Midwestern mesoregion.

Keywords: Fight for the land, Agrarian reform, Occupations of land.

Resumen: los conflictos rurales existentes en la actualidad son consecuencias de un proceso histórico de desterritorialización y exclusión desde el avance del capitalismo en la agricultura. Movimientos socioterritoriales, como el MST, desafían el poder hegemónico y la legalidad de la propriedad capitalista, movilizando los campesinos 
y ocupando tierras que no cumplen la función social convirtiendo así en territorios de reforma agraria en la provincia de Paraná. El objetivo de este artículo, apoyado por datos de campo y referencias bibliográficas, es estudiar la colonización, transformaciones territoriales y conflictos rurales en la ciudad de Barbosa Ferraz en la mesorregión del medio oeste de Paraná.

Palabras-clave: Lucha por la tierra, Reforma agraria, Ocupaciones de tierra.

\section{INTRODUÇÃO}

Para compreendermos os conflitos rurais existentes no município de Barbosa Ferraz, localizado na Microrregião de Campo Mourão e na Mesorregião Centro-Ocidental do Paraná, dependemos inicialmente do entendimento acerca do processo de colonização e das transformações desse território. Essas transformações decorrem, principalmente, das relações sociais que geraram e que geram a desterritorialização e a reterritorialização ${ }^{1}$ de diferentes grupos sociais, implicando, de modo contínuo e contraditório a criação de distintos territórios e territorialidades.

Em linhas gerais, a história da colonização de Barbosa Ferraz foi marcada pela política de concessão de terras devolutas em troca da prestação de serviços. Nesse sentido, na década de 1920 a área hoje equivalente ao município foi parte da concessão realizada em benefício de uma única pessoa como pagamento pela construção de uma estrada na região Sudeste do estado. Vinte anos depois, na década de 1940, esse território foi negociado com uma empresa colonizadora que passou a lotear e comercializar a terra. A iniciativa da empresa estava alinhada com as caraterísticas naturais da região e com os interesses econômicos da época. Por essa razão, inicialmente foi a cafeicultura a atividade responsável por atrair os primeiros colonos. É válido relembrar que o café foi bastante importante para as economias nacional e estadual e responsável pela ocupação e colonização da porção norte do estado do Paraná.

A partir da década de 1960 a cultura do café foi substituída pelo da hortelã que, desde então, assumiu o protagonismo econômico e estimulou, efetivamente, a ocupação do território. O ciclo da hortelã persistiu em Barbosa Ferraz até início da década de 1970, até o encerramento da atividade como resultado do esgotamento do solo decorrente da excessiva exploração.

No mesmo período em que o cultivo de hortelã encerrava-se no município, o Paraná iniciava o processo de modernização agrícola, caracterizado pela industrialização da agricultura por meio da adoção de um novo modelo produtivo composto por maquinários, adubos químicos e agrotóxicos. A modernização representou a expansão do capitalismo no campo. Conforme esse novo modelo criou territorialidades cada vez mais ligadas ao

1 De acordo com Haesbaert (2011), a desterritorialização define-se como o movimento de abandono, de destruição dos territórios socialmente construídos. Já a reterritorialização é o processo de construção do território a partir de novos agenciamentos. Os dois movimentos são concomitantes e indissociáveis, o que significa que a destruição do território (desterritorialização) de um determinado grupo social implica a construção do território (reterritorialização) de outro grupo, com novos tipos de relações, formas de organização e divisão do trabalho, isto é, novos agenciamentos. 
capital, contribuiu para que muitos trabalhadores fossem expropriados e desterritorializados do campo, provocando inúmeros conflitos por terra espalhados por todo o estado. Parcela desses conflitos resultou em ocupações realizadas por famílias camponesas vinculadas a movimentos socioterritoriais, entre eles o Movimento dos Trabalhadores Rurais Sem Terra (MST).

Como na maior parte do estado, em Barbosa Ferraz a introdução da modernização transformou as relações de trabalho, o perfil das propriedades rurais e, consequentemente, o território. Atualmente existem no município duas ocupações de terra, ambas ligadas ao MST: o pré-assentamento Irmã Dorothy, iniciado em 2005, quando um grupo de aproximadamente 50 famílias ocupou 573,20 hectares; o acampamento Nossa Senhora do Carmo, cuja trajetória de luta iniciou-se no ano de 2006.

Para cumprirmos com o objetivo proposto, abordando a história do município desde a colonização até os conflitos rurais recentes, este trabalho vale-se de pressupostos teóricos e de procedimentos empíricos. No que concerne aos pressupostos teóricos, utilizamos dados estatísticos coletados dos materiais disponibilizados pelo Instituto Brasileiro de Geografia e Estatística (IBGE) e publicações que tratam dos temas território, colonização, modernização agrícola e reforma agrária, por exemplo, Raffestin (1993), Andrade (2013), Yokoo (2013), Silva (1981, 1985), Martins (1981), Fernandes $(2001,2008)$ e outros.

No que tange aos procedimentos empíricos, realizamos trabalhos de campo, nos quais efetuamos registros fotográficos e coletamos documentos e informações por meio de entrevistas semiestruturadas, realizadas com dois pioneiros do município e com 15 trabalhadores sem-terra. A seleção da amostra dos entrevistados foi realizada tanto aleatoriamente quanto perante a identificação de casos mais representativos. Os relatos foram registrados com o uso de um gravador e, depois, transcritos, sem correção ortográfica, sendo que alguns trechos são utilizados ao longo do texto. A identificação das falas é efetuada pelo uso dos nomes dos entrevistados mediante prévia autorização. Para a análise das publicações e dos materiais obtidos nos campos, buscamos construir uma perspectiva crítica, capaz de contemplar as contradições, a dinâmica e o movimento histórico do processo estudado.

O texto segue dividido em três partes. Na primeira, é apresentada, brevemente, nossa compreensão acerca do conceito de território e os principais autores que orientam nossas reflexões. Na segunda, discutimos a colonização, as formas de uso da terra e as transformações do território em Barbosa Ferraz. Na terceira, tratamos, sucintamente, dos conflitos rurais existentes no município e dos seus desafios, com maior atenção para o pré-assentamento Irmã Dorothy por esse ser o caso de maior dimensão.

\section{O TERRITÓRIO COMO BASE E COMO PRODUTO DAS RELAÇÕES SOCIAIS}

No território se materializam as relações sociais, marcadas pelas intencionalidades, por manifestações de poder, por disputas e por conflitos que, historicamente, modelam a sociedade. Andrade (2013) afirma que as discussões sobre o conceito de território na 
geografia são marcadas por uma grande controvérsia desde sua origem até o presente. Em função da complexidade desse debate, nosso objetivo não é fazer uma revisão bibliográfica das diferentes leituras acerca da definição de território, mas sim demarcar nossa interpretação dessa definição e quais autores guiam nossas reflexões.

Em uma concepção mais ampla, compreendemos o território para além do espaço de governança, como determina sua definição clássica unidimensional (Raffestin, 1993; Fernandes, 2008; Haesbaert, 2011). Entendemos que, assim como explica Raffestin (1993), o território é produzido a partir do espaço geográfico, configurando-se em espaço territorializado, isto é, apropriado concreta ou abstratamente e determinado por relações sociais. Dessa forma, o território é “... resultado de uma ação conduzida por um ator sintagmático (ator que realiza um programa) em qualquer nível" (Raffestin, 1993, p. 143). Em outras palavras, é o espaço modificado pelas ações humanas, pelas projeções de trabalho, de energia e de informação (Raffestin, 1993). Com base nessa leitura, concebemos que o território é, ao mesmo tempo, a base em que as relações sociais se materializam e o produto dessas mesmas relações que o estruturam na forma como o conhecemos.

Nessa perspectiva, os princípios da multidimensionalidade e da multiescalaridade são fundamentais para compreendermos o território. A multidimensionalidade significa que o território é constituído a partir das dimensões política, econômica, social, cultural e ambiental (Raffestin, 1993; Fernandes, 2008; Haesbaert, 2011). A multiescalaridade revela que o território está organizado em “... diversas escalas geográficas, desde a local até a escala internacional" (Fernandes, 2008, p. 276). Nesse sentido, podemos pensar o território desde um país até um estado, um município, um assentamento, um lote.

Todas as dimensões do território estão interligadas. Por isso, ao se explorar uma delas, todas as outras estão envolvidas. Portanto, o conjunto dessas dimensões manifesta-se em todas as escalas, que também estão interligadas, considerando que "... uma ação política tem desdobramentos em vários níveis ou escalas: local, regional, nacional, internacional" (Fernandes, 2008, p. 277). Por essa razão, cada unidade territorial é uma totalidade, sendo esse outro princípio importante para pensarmos o território (Fernandes, 2008; Torres, 2011).

Enquanto totalidade, o território é marcado pela conflitualidade, isto é, pelas disputas que o movimentam, fazendo com que esteja permanentemente em transformação. As disputas territoriais revelam o poder exercido de forma intencional e não subjetiva pelas classes sociais, com o objetivo de defender ou de impor interesses, de criar ou de preservar territorialidades (Raffestin, 1993). Segundo Saquet (2007, p. 32), o poder não é uma instituição, mas, sim, “ ... o nome que se dá a uma situação complexa da vida em sociedade". Desse modo, entendemos que o poder não emana apenas dos aparelhos do Estado, tampouco é algo que se adquire, mas é exercido nas relações desiguais e heterogêneas que envolvem "... outros processos da vida cotidiana, como a família, as universidades, a igreja, o lugar de trabalho etc." (Saquet, 2007, p. 32). Segundo Raffestin (1993, p. 53), o poder é parte inerente das relações sociais, sendo que não existe “... uma oposição binária e global entre dominador e dominados".

As relações dissimétricas de poder geram os movimentos de desterritorialização e reterritorialização dos grupos sociais. Segundo Haesbaert (2011), podemos, simplificadamente, 
definir a desterritorialização como o abandono, a destruição dos territórios historicamente construídos. Em contrapartida, a reterritorialização é a construção do território mediante a formação de novos códigos e agenciamentos. Na mesma linha, Pedon (2009) corrobora com as definições de desterritorialização e reterritorialização, ao afirmar que:

... a desterritorialização é entendida como perda do território apropriado e vivido em razão de diferentes processos capazes de desfazerem o território, já a reterritorialização compreende o processo de criação de novos territórios, seja por meio da reconstrução parcial de antigos territórios, seja por meio da recriação parcial (em outros lugares) de um território novo que contém, também, parcela das características do velho território. (Pedon, 2009, pp. 221-222).

Esses processos são concomitantes e indissociáveis, o que significa que toda desterritorialização produz uma reterritorialização, uma vez que não existe sujeito sem território. Sendo assim, podemos pensar a vida como um constante "... movimento de desterritorialização e reterritorialização, ou seja, estamos sempre passando de um território para o outro, abandonando territórios, fundando novos. A escala espacial e a temporalidade é que são distintas" (Haesbaert, 2011, p. 138).

Compreendemos que as relações sociais e o contínuo movimento de desterritorialização e reterritorialização provocam as transformações do território. O Estado e o Capital são agentes determinantes nesse processo (Haesbaert, 2011). Quando olhamos para Barbosa Ferraz, podemos pensar a colonização como a primeira grande transformação, resultante da reterritorialização do Estado e do Capital mediante a destruição dos territórios tradicionais e a desterritorialização dos povos ocupantes.

Por conseguinte, o desenvolvimento dos ciclos econômicos desdobrou novos movimentos de desterritorialização e reterritorialização, refletindo-se na construção de territorialidades cada vez mais ligadas ao capital. Os conflitos rurais são resultados desse processo, expressam a contestação do modelo dominante e a luta dos grupos excluídos pela conquista de territórios para a reprodução dos seus modos de vida. É com base nessa discussão que seguimos adiante, tratando da colonização e das transformações do território no recorte geográfico em questão.

\section{BARBOSA FERRAZ: COLONIZAÇÃO, USOS DA TERRA E TRANSFORMAÇÕES DO TERRITÓRIO}

Barbosa Ferraz é um município de 538,6 km² de extensão territorial, localizado na Microrregião de Campo Mourão e na Mesorregião Centro-Ocidental do Paraná, que limita com os municípios de Fênix, Corumbataí do Sul, Luiziana, Godoy Moreira, Peabiru, Iretama e São João do Ivaí (Fig. 1). 
Figura 1: Mapa de localização de Barbosa Ferraz, PR.

Mapa de localização de Barbosa Ferraz - PR
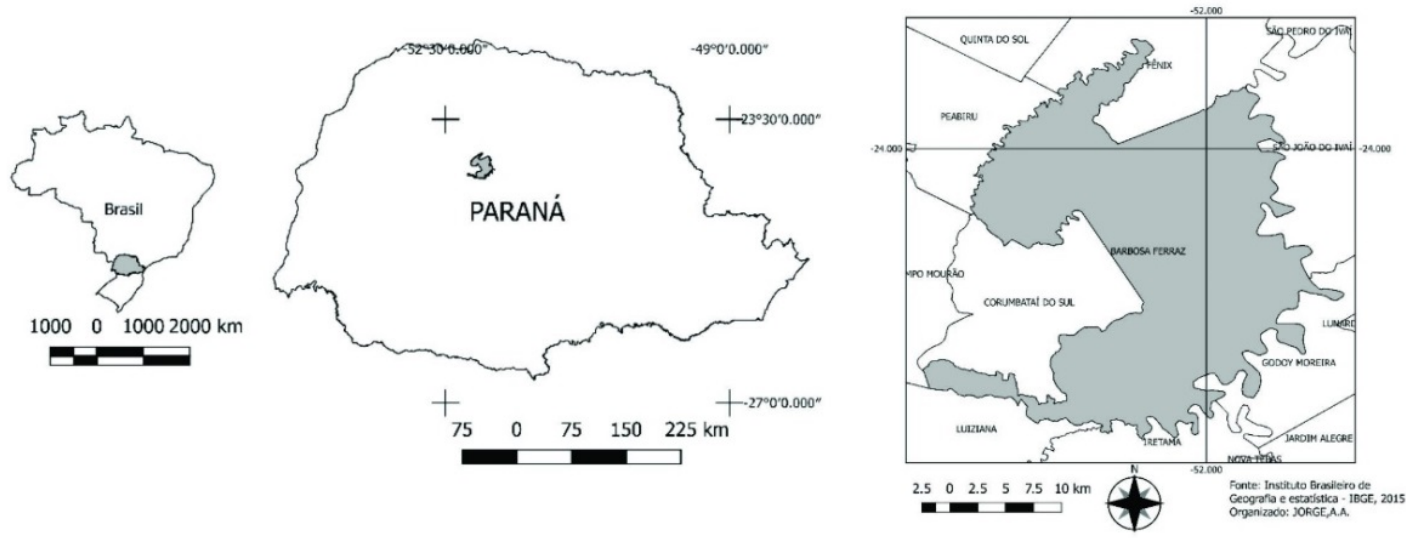

Fonte: elaborado a partir de IBGE (2015).

Para discutirmos o processo de colonização do município, é importante destacarmos que, assim como assevera Andrade (2013), colonizar significa apropriar-se, privadamente, da terra de acordo com interesses econômicos, realizando um povoamento seletivo, com base na restrição do acesso à terra por determinada parcela da sociedade. Partindo dessa concepção, compreendemos a colonização como a destruição das territorialidades tradicionais e, consequentemente, a desterritorialização dos povos ocupantes, visando a liberação de espaço para a construção de novas territorialidades estruturadas dentro da lógica capitalista (Andrade, 2013).

Esse processo, no caso do Paraná, foi em grande parte dirigido pelo Estado que, em algumas regiões promoveu a colonização e, em outras concedeu parcelas de terra para a iniciativa privada sob a justificativa de que o poder público apresentava dificuldades econômicas e falta de capacitação técnica para construir novos núcleos coloniais (Yokoo, 2013). De modo proposital e estratégico, ficou sob a responsabilidade do poder público promover projetos de colonização nas áreas consideradas impróprias ou pouco produtivas em função das características naturais e dos interesses econômicos da época (Andrade, 2013). Parte das terras que ficou sob a responsabilidade do Estado foi utilizada por meio de concessões como pagamento pela realização de serviços e de obras de infraestrutura pública (Yokoo, 2013). Entre essas concessões, está a realizada em 1928 em nome do engenheiro civil Joaquim Vicente de Castro, que, na época, recebeu uma extensão territorial equivalente à área dos atuais municípios de Fênix, Corumbataí do Sul e Barbosa Ferraz. “Essa concessão era parte do pagamento da construção de uma estrada que ligava o município de Irati e Itapará" (Andrade, 2013, p. 95).

Em 1948, o engenheiro negociou a porção de terra equivalente a Barbosa Ferraz com a Concessionária e Imobiliária Paraná Ltda., que, a partir de então, passou a realizar a derrubada da mata, a divisão da terra e a comercialização dos lotes, fundando, a princípio, a vila Barbosa Ferraz (Luciani \& Colavite, 2014).

O interesse da concessionária em promover a colonização nessa porção de terra estava relacionado à cafeicultura, atividade que foi bastante representativa para a economia 
nacional e que alavancou a colonização da região norte-paranaense. Para atrair compradores, a empresa aproveitou-se de algumas características naturais da região, tais como a topografia e o tipo de solo proveniente da decomposição de rochas basálticas, popularmente conhecido como 'terra roxa' e considerado apropriado para o cultivo de café.

Segundo o depoimento do pioneiro José Ricardo Villar, os primeiros colonos chegaram na área por volta de 1949, oriundos, principalmente, de São Paulo e Minas Gerais, estados que tinham tradição na cafeicultura. Ao comentar sobre esse processo, o pioneiro José nos conta parte da história da sua família, que veio para Barbosa Ferraz no ano de 1952: "Eles foram um dos primeiros a chegar, as primeiras casas, tava só derrubado, eles derrubavam e queimavam o mato, a cidade já tava cortada, mas não tinha muita coisa, as primeiras casas foram eles mesmo que ajudaram a construir. Meu avô veio com a família toda pra cá, meu pai acompanhou ele, eles vieram de Ouro Fino, Minas Gerais. No caso do meu pai, ele seguiu mais o pai dele, porque eles eram lá em Minas da tradição do café, na época, e eles vieram visitar aqui e gostaram das terras, que eram vermelhas, e porque tinha muito "espigão" que eles chamavam, que era "morro". Espigão, pra eles, lá em Minas Gerais, era o lugar de plantar o café, e eles eram apaixonados, gostavam demais do plantio de café, e eles vieram pra cá entusiasmado com isso, plantar café e foi o que fizeram, compraram o sítio aqui, derrubaram o mato e plantaram café".

Com base nesse relato, é possível associarmos o deslocamento da família do Sr. José à crise da cafeicultura que, na segunda metade do século XIX, desestimulou o plantio da cultura nas zonas produtoras mais antigas que, entre outros fatores, encontravam-se naturalmente desgastadas, a exemplo, os casos de São Paulo e de Minas Gerais (Serra, 1992).

Nessa perspectiva, a formação de correntes migratórias em busca de novas terras para o plantio do café significou a reterritorialização dos produtores dessa atividade, revelando “... um movimento dialético de continuidade e descontinuidade" (Andrade, 2013, p.7). À medida que esses produtores impulsionavam a frente cafeeira, também estimulavam a colonização e, naturalmente, imprimiam uma nova forma de organização do território.

No caso de Barbosa Ferraz, o café foi produzido no mesmo molde que nas zonas produtoras da região Norte do Paraná, ou seja, era regularmente cultivado em pequenas e médias propriedades, por meio do trabalho familiar e das relações de parceria. O café não era produto exclusivo das propriedades rurais, junto a ele, cultivavam-se pastagens, algodão, lavouras temporárias e outros (Cancian, 1981).

Ao contrário do que aconteceu na região Norte do Estado, a expectativa gerada pelo plantio de café durou pouco em Barbosa Ferraz (localizado na região Centro-Ocidental), o que está principalmente relacionado às condicionantes climáticas. O município está localizado em uma região suscetível a geadas, sobretudo a porção localizada ao sul do paralelo $24^{\circ}$, onde a ocorrência do fenômeno é mais intensa e frequente (Yokoo, 2013).

Dessa forma, poucos anos após a fixação da cultura, os produtores foram surpreendidos com uma forte geada que dizimou os cafezais. Esse episódio é relatado pelo pioneiro José: "quando o café tava formando, ia começar a produzir, veio uma geada muito forte, em 1955, eu me lembro disso, eu era criança, ficou todo mundo a zero, uma dificuldade danada". Essa história também é contada em entrevista pelo pioneiro Nelson Carlos Ferreira, que acrescenta que, no período subsequente à geada, os produtores ficaram desanimados, 
muitos abandonaram a cafeicultura, ingressando nos cultivos de milho e de feijão, todavia tiveram dificuldades para encontrar compradores para a produção.

De acordo com o pioneiro Nelson, a partir do final de 1960, uma nova cultura foi introduzida no munícipio, o plantio de hortelã. As primeiras mudas vieram de Presidente Prudente (SP), trazidas pelos irmãos Carlos e Brasilino Francioli. O objetivo, na época, não era comercializar a hortelã in natura, mas, sim, o óleo extraído por meio da destilação realizada em alambiques.

As condições naturais da região foram favoráveis à implantação da cultura, que também possuía compradores e era negociada com preço satisfatório. A junção desses fatores contribuiu para que, rapidamente, os agricultores se interessassem pelo cultivo, tornando-se, assim como chama o senhor Nelson, "uma febre" que durou do início da década de 1960 até meados da década de 1970. A hortelã substituiu o café, tornando-se protagonista no cenário econômico do município.

Segundo o pioneiro José, depois de que o plantio era efetuado, realizavam-se cortes manuais aproximadamente quatro vezes ao ano, exceto no período do inverno, em que a planta não apresentava crescimento satisfatório. Após o corte, as ramas de hortelã eram carregadas em carroças e transportadas até o alambique, onde era realizado o procedimento para a extração do óleo.

No entanto a herbácea podia ser cultivada apenas duas vezes no mesmo terreno (Yokoo, 2013). Depois de dois anos a fertilidade natural do solo era reduzida, causando implicações à produtividade. Os produtores deixavam então as áreas degastadas e derrubavam matas em busca de solos aptos a receber as mudas. O pioneiro Nelson explicounos esse processo ao dizer que "o hortelã exigia terras férteis e novas e não aceitava adubação, conforme as terras iam ficando velhas, novas matas eram derrubadas para isso".

O plantio de hortelã não causou grandes modificações na estrutura fundiária e na divisão do trabalho em Barbosa Ferraz se considerarmos que, assim como o café, a cultura era cultivada em pequenas e em médias propriedades, utilizando mão de obra familiar. De acordo com o pioneiro José, na proporção em que a hortelã se difundiu entre os produtores, várias indústrias de alambiques instalaram-se no munícipio, desenvolvendo, paralelamente, uma atividade econômica voltada à área urbana.

A demanda por trabalhadores e a propaganda em torno da lucratividade da hortelã fizeram com que o município, na época, tornasse-se polo de atração populacional, sobretudo, para os mineiros que, de acordo com o pioneiro Nelson, "... chegavam em caminhões chamados pau-de-arara, os quais diziam que estavam vindo pegar dinheiro com o rastelo, que usava para juntar as ramas de hortelã". Nesse período, Barbosa Ferraz foi considerada a Capital Mundial da Hortelã. Os comentários sobre o sucesso dos produtores que exerciam a atividade atraíam tantas famílias que, segundo o censo demográfico de 1970 do IBGE, o município atingiu o auge de 37.455 habitantes.

Entre as histórias relacionadas a esse período, destaca-se a maneira como costumava ser realizado o pagamento pelo óleo de hortelã. Segundo o senhor José, as empresas compradoras, normalmente, oriundas de Presidente Prudente, enviavam um avião, que sobrevoava a área e jogava pacotes de dinheiro em pontos previamente combinados para 
serem apanhados por funcionários encarregados de efetuar o pagamento aos produtores. Segundo o pioneiro José "o pagamento pelo óleo era feito pelo avião, não tinha banco, não tinha nada, o avião jogava dinheiro para os compradores pagar o produto". A escolha de efetuar o pagamento por meio de um avião era consequência da falta de estrutura e da dificuldade de acessar o município. Na época, o transporte dependia de balsas que permitiam a travessia pelos rios Ivaí e Corumbataí.

O avião mencionado está retratado no painel localizado na praça da prefeitura do município, como forma de representar a importância da comercialização de óleo de hortelã para o desenvolvimento local (Fig. 2).

Figura 2: Painel localizado na praça da prefeitura do município de Barbosa Ferraz, PR.No detalhe, retrata o avião que realizava o pagamento pelo óleo de hortelã.
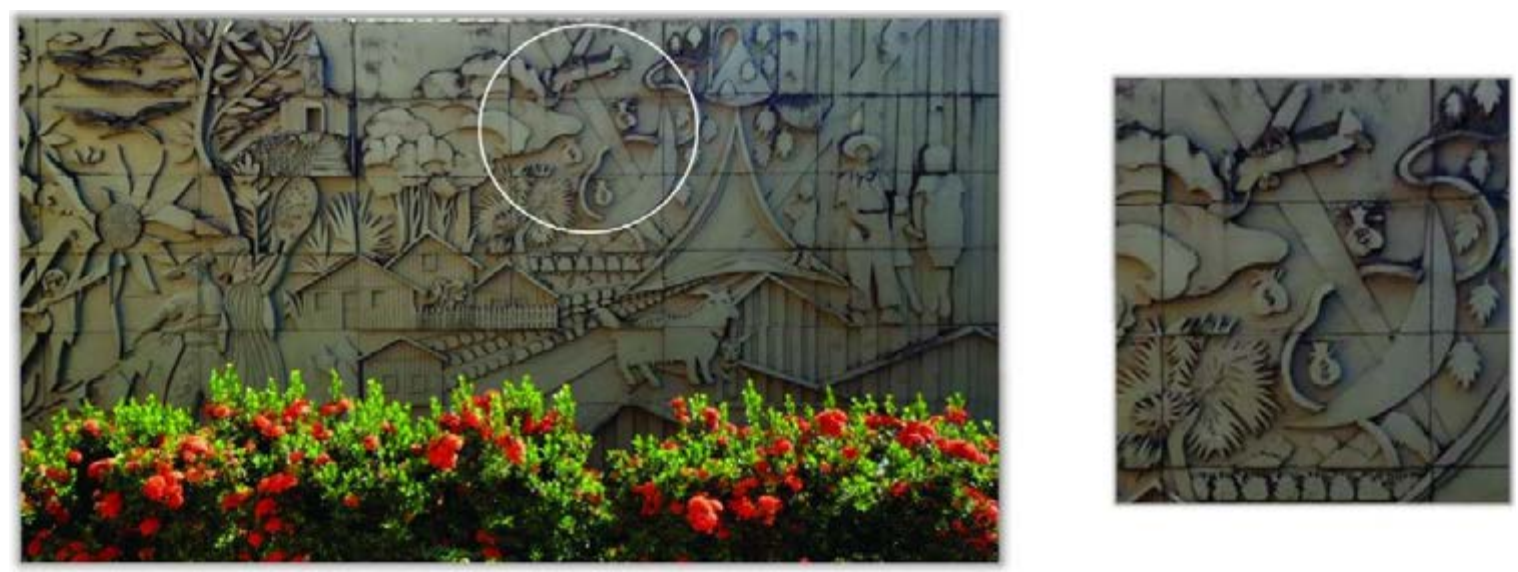

Mesmo com o sucesso obtido, o cultivo de hortelã findou no início da década de 1970, resultado do esgotamento do solo, tal como afirma o pioneiro José: “... com o tempo, as terras ficaram fracas, né, foi muita exploração por causa do hortelã, já não produzia mais como antes, já não compensava mais plantar, aí as pessoas foi desistindo". Com o encerramento do ciclo, alguns produtores tentaram retomar o plantio de café, outros partiram para a produção de algodão, de milho e de feijão, entretanto, nenhuma dessas culturas prosperou no município como a hortelã.

Nessa mesma década o Paraná inseria-se na modernização agrícola, caracterizada pela expansão do capitalismo no campo (Martins, 1981), com base na industrialização da agricultura, por meio da introdução de maquinários, adubos químicos e agrotóxicos na produção (Silva, 1985). Segundo Silva $(1981,1985)$, a modernização está inserida no contexto das políticas econômicas implementadas após a segunda Guerra Mundial, com a intenção de superar o subdesenvolvimento, sendo que, para isso, “ . . a a industrialização era apresentada como a fórmula milagrosa capaz de, por si só, gerar o desenvolvimento; e o setor agrícola, apontado como o responsável pelo atraso desse país ..." (Silva, 1981, p. 17).

Dessa forma, compreendemos que a modernização significou a implantação de um novo modelo agrícola, sustentado na incorporação de insumos industriais na agricultura, com a finalidade de tornar a produção mais intensiva. No Paraná, o novo modelo foi marcado pela introdução da soja em alternância com outros plantios, tais como os de milho e 
de trigo. Esses cultivos têm como principal destino o mercado externo. Em Barbosa Ferraz, essas lavouras substituíram o cultivo de hortelã nas partes planas, mecanizáveis. As áreas com maior declividade foram ocupadas por pastagens.

Ao tratar dos desdobramentos gerais da modernização, Silva (1981) explica que o novo modelo atendeu, sobretudo, a duas necessidades elementares para a ampliação capitalista. Uma delas foi a criação de um mercado consumidor interno para os produtos industriais; a outra foi a liberação de mão de obra para alimentar a indústria nascente. No que se refere ao mercado consumidor interno, o Estado desempenhou um papel importante, por meio dos programas de crédito rural, que não contemplaram em igualdade de condições todos os trabalhadores, acentuando a desigualdade social no campo (Silva, 1981). A união entre agricultura e indústria tornou o campo dependente da cidade e possibilitou a apropriação da renda da terra pelo capital financeiro, industrial e comercial, por meio dos empréstimos bancários realizados para financiar a adequação ao novo modelo, do controle dos preços dos insumos utilizados na produção até a regulação da comercialização dos produtos agrícolas voltados à exportação (Martins, 1981; Oliveira, 2001).

Já a liberação de mão de obra no campo precisa ser associada à mecanização, empregada no sentido de substituir o trabalho humano, desdobrando-se na redução do período de ocupação, na sazonalidade do emprego e, consequentemente, na expropriação e na desterritorialização de grande parte dos trabalhadores rurais (Silva, 1981; Martins, 1981; Oliveira, 2001). Ao discutir esse processo, Stédile e Fernandes (2012) acrescentam que o contingente populacional expulso do campo nesse período era formado por famílias que viviam como arrendatárias e parceiras ${ }^{2}$. Essas famílias eram acostumadas a uma agricultura que utilizava muita mão de obra e pouca máquina:

A mecanização da lavoura e a introdução, digamos, de uma agricultura com características mais capitalistas expulsaram do campo, de uma maneira muito rápida, grandes contingentes populacionais naquela década. Eram famílias que viviam como arrendatárias, parceiras ou filhos de agricultores que recebiam um lote desmembrado da já pequena propriedade agrícola de seus pais. Foi um período em que a natureza principal da agricultura era o uso intensivo de mão de obra. Não sei se é justo dizer que era uma agricultura atrasada - penso que aqui não cabem comparações -, que utilizavam muita mão de obra e pouca mecanização. Com a entrada da mecanização, liberou-se um enorme contingente de pessoas. (Stédile \& Fernandes, 2012, pp. 17-18)

Nessa perspectiva, entendemos que a expropriação e a desterritorialização significaram a separação entre os trabalhadores e a terra, que consiste no instrumento fundamental de produção no campo (Martins, 1981; Oliveira, 2001). Ao serem desterritorializados, esses trabalhadores tornaram-se “... libertos de toda propriedade que não seja a propriedade da sua força de trabalho, da sua capacidade de trabalhar ... não têm outra alternativa senão a de vender a sua força de trabalho ao capitalista, ao patrão" (Martins, 1981, p. 152). A

2 Parceria e arrendamento são instrumentos criados pelo Estatuto da Terra (Lei ${ }^{\circ} 4.504 / 64$ ), para regulamentar a posse e o uso temporário da terra, por meio de contratos estabelecidos entre proprietários e trabalhadores. A principal diferença entre os dois instrumentos é que o arrendamento prevê o pagamento pelo uso da terra em dinheiro, ou seja, a transferência da renda camponesa da terra para o proprietário. Já a parceria consiste no pagamento pelo uso da terra em produtos, portanto, na transferência da renda camponesa para o proprietário (Oliveira, 2001). 
partir desse processo, percebemos o desenvolvimento do assalariamento no campo (relação de trabalho capitalista), que, em conjunto com a sazonalidade do emprego, repercutiu na formação de fluxos migratórios e no surgimento do sujeito 'boia-fria' (Oliveira, 2001).

Em Barbosa Ferraz, podemos observar a implantação e os impactos do novo modelo agrícola por meio de vários indicadores, tais como o aumento do número de tratores, de máquinas de plantio e colheita e do uso de adubos químicos. Segundo os dados da Tabela 1, as maiores diferenças estão entre as décadas de 1970 e de 1980, período em que a modernização estava em curso no estado e, consequentemente, no município, demandando elevados investimentos. Dessa forma, entre 1970 e 1980 o número de tratores no município aumentou $471,4 \%$. Com relação às máquinas de plantio e de colheita, houve um crescimento ainda maior, correspondente a $3.240 \%$. O mesmo ocorreu com a adubação química, com um aumento de $1.715 \%$.

Tabela 1: Indicadores da modernização agrícola em Barbosa Ferraz, PR (1970-2017).

\begin{tabular}{l|c|c|c|c|c}
\hline Indicadores & $\mathbf{1 9 7 0}$ & $\mathbf{1 9 8 0}$ & $\mathbf{1 9 9 6}$ & $\mathbf{2 0 0 6}$ & $\mathbf{2 0 1 7}$ \\
\hline N. o de tratores & 63 & 360 & 399 & 370 & 389 \\
\hline N. o de máq. plantio/colheita & 15 & 502 & 180 & 205 & 265 \\
\hline Adubação química & 40 & 726 & 682 & 1561 & 411 \\
\hline
\end{tabular}

Fonte: elaborado a partir de IBGE (1970, 1980, 1996, 2006, 2017).

Após a consolidação da modernização, percebemos, nos anos seguintes $(1996,2006$, 2017), a estabilização do número de tratores no município. Já a quantidade de máquinas de plantio e de colheita contraiu-se consideravelmente no ano de 1996 para, posteriormente (2006 e 2017), atingir determinada estabilidade. A adubação química apresentou um relevante crescimento em 2006, seguida de redução em 2017, o que, entre outros fatores, pode indicar que, em 2006, o município enfrentou problemas associados ao desgaste do solo, repercutindo-se na produtividade. É importante lembrarmos que, no final da década de 1980, Barbosa Ferraz perdeu área territorial devido à emancipação política e administrativa de Corumbataí do Sul (Andrade, 2013), o que influencia os dados a partir desse período, justificando, por um lado, a redução de parte dos indicadores, em especial no ano de 1996.

Por outro lado, essa redução também pode justificar-se pelo fato de que parcela dos pequenos proprietários que, inicialmente, tentaram inserir-se no novo modelo não obteve os resultados esperados, chegando, em muitos casos, a perder a propriedade. A desterritorialização dessa parcela de produtores revela outra característica da modernização: a concentração fundiária, gerada a partir da absorção das pequenas unidades produtivas principalmente nos períodos de subida do ciclo econômico (Silva, 1985). A concentração fundiária é indicativo da concentração da riqueza, considerando a importância da terra como fonte de prestígio, de poder político e econômico e de acesso a outras formas de riqueza (Silva, 1981).

Nesse sentido, em algumas regiões do Paraná, o desenvolvimento do capitalismo no campo representou a modificação da estrutura fundiária implantada na colonização, caracterizada pela divisão da terra em pequenas propriedades (Silva, 1981). Em Barbosa Ferraz, podemos perceber esse movimento de absorção das pequenas unidades produtivas 
(Tab. 2): em 1970, os estabelecimentos com menos de 10 ha ocupavam, no município, uma área total de 16.243 ha. Uma década depois, em 1980, esses estabelecimentos passaram a ocupar uma área de 7.659 ha, indicando a liberação de 8.584 ha.

As terras que saíram dos minifúndios ${ }^{3}$ (menos de 10 ha) foram transferidas para os outros estratos da estrutura fundiária, principalmente, para as médias e as grandes unidades produtivas, que, nesse mesmo período, apresentaram crescimento. Em 1970, os estabelecimentos entre 10 e 100 ha ocupavam uma área de 21.522 ha; em 1980, esse número cresceu para 29.568 ha, evidenciando a incorporação de 8.046 ha. A diferença é muito maior quando analisamos a área ocupada pelos estabelecimentos de 100 ha a menos de 1.000 ha, que aumentaram de 6.499 ha, em 1970, para 27.147 ha, em 1980, assinalando a absorção de 20.648 ha. Além disso, na década de 1980, o IBGE registrou unidades produtivas com mais de 1.000 ha, modelo que não existia no município na década anterior. Juntos, esses estabelecimentos somavam 5.277 ha.

No censo agropecuário de 1996, temos a diminuição da área ocupada em todos os estratos fundiários, o que pode ser um reflexo da emancipação de Corumbataí do Sul. Todavia, os estabelecimentos com menos de 10 ha foram o que mais perderam área (4.164 ha), o que nos indica que a absorção dos minifúndios continuou acontecendo após a fase de consolidação da modernização, e que a sobrevivência no campo tornou-se difícil para aqueles que possuíam pouca terra, sendo muito comum relatos de endividamento e aprofundamento do empobrecimento. Em 2006, observamos que, de modo geral, todos os estratos fundiários expandiram a área ocupada, com destaque para os estabelecimentos de 100 a menos de 1000 ha, que, no total, incorporaram 7.287 ha. Já em 2017, percebemos a redução da área ocupada em todos os estratos, sendo que os minifúndios e as pequenas propriedades foram novamente os mais afetados, liberando, juntos, o total de 15.277 ha.

Tabela 2: Estabelecimentos agropecuários por grupos de área total em Barbosa Ferraz, PR (1970-2017).

\begin{tabular}{l|c|c|c|c|c}
\hline Estabelecimentos & $\mathbf{1 9 7 0}$ área (ha) & $\mathbf{1 9 8 0}$ área (ha) & $\mathbf{1 9 9 6}$ área (ha) & $\mathbf{2 0 0 6}$ área (ha) & $\mathbf{2 0 1 7}$ área (ha) \\
\hline $0<10$ hectares & 16.243 & 7.659 & 3.495 & 3.546 & 1.655 \\
\hline $10<100$ hectares & 21.522 & 29.568 & 18.119 & 18.931 & 5.545 \\
\hline $100<1000$ hectares & 6.499 & 27.147 & 21.245 & 28.532 & 28.355 \\
\hline$>1000$ hectares & 0 & 5.277 & 4.596 & 4787 & 0
\end{tabular}

Fonte: elaborado a partir de IBGE (1970, 1980, 1196, 2006 e 2017).

As transformações trazidas pela modernização, principalmente em sua fase de consolidação (durante as décadas de 1970 e de 1980), fizeram com que muitos dos trabalhadores desterritorializados do campo não tivessem nova oportunidade na agricultura, tendo que se mudar para as cidades “... em busca de uma nova maneira (nem sempre satisfatória) de ganhar a vida" (Silva, 1985, p. 38). Em um primeiro momento, esses trabalhadores seguiram para os núcleos mais próximos, porém, “. .. como nem sempre conseguiam emprego,

3 De acordo com o Instituto Nacional de Colonização e Reforma Agrária (INCRA), pequena propriedade é aquela cuja área varia de um a quatro módulos fiscais, média propriedade varia de quatro a quinze módulos fiscais e a grande é superior a quinze módulos. O módulo fiscal em Barbosa Ferraz corresponde a 20 hectares, sendo assim, os imóveis com área inferior a 20 ha são considerados minifúndios, já aqueles com área entre 20 ha e 80 ha são considerados pequenas propriedades, os com área de 80 ha a 300 ha são médias propriedades e os com área acima de 300 ha são grandes propriedades. 
foram se aventurando para as cidades de maior porte e, em seguida, para outros Estados" (Serra, 2009, p. 8).

Em função desses deslocamentos, muitos municípios da região que antes da modernização haviam sido polos de atração populacional tornaram-se dispersores, sendo esse o caso de Barbosa Ferraz. Conforme a Tabela 3, a população total de Barbosa Ferraz reduziu para cerca de um terço em 40 anos12.656 habitantes, com a estimativa para 2019 de 11.568 habitantes.

Tabela 3: População de Barbosa Ferraz, segundo os censos demográficos (1970 - 2010).

\begin{tabular}{c|c|c|c}
\hline Ano & População total & População rural & População urbana \\
\hline 1970 & 37.455 & 31.550 & 5.905 \\
\hline 1980 & 36.156 & 25.448 & 10.708 \\
\hline 1991 & 18.389 & 7.517 & 10.872 \\
\hline 2000 & 14.110 & 4.375 & 9.735 \\
\hline 2010 & 12.656 & 3.075 & 9.581 \\
\hline
\end{tabular}

Fonte: elaborado a partir de IBGE (1970, 1980, 1991, 2000, 2010).

A maior redução populacional ocorreu justamente entre as décadas de 1980 e de 1990, período em que os resultados da modernização já pesavam sobre os trabalhadores. Também foi o período em que ocorreu a emancipação de Corumbataí do Sul, consequentemente, o município perdeu habitantes. Além da queda populacional, os dados referentes a essas décadas revelam uma inversão quantitativa relacionada à situação de domicílio da população do município. Em 1980, 70,3\% residiam na zona rural; em 1990, apenas 40,8\% residiam no campo.

Diante desse contexto, compreendemos a modernização como um processo de exclusão e de desterritorialização, sustentado na relação entre o capital e o Estado em desfavor da população (Andrade, 2013). A velocidade com que ocorreram as transformações levou à intensificação da desigualdade social e dos conflitos, sobretudo porque parte dos trabalhadores não aceitaram a desterritorialização, ou ainda, não conseguiram encaixar-se nas atividades urbanas, "... transformando-se em trabalhadores sem-terra, em busca do acesso à terra" (Andrade, 2013, p. 115).

Muitas dessas famílias se juntaram aos movimentos socioterritoriais, definidos como aqueles que possuem suas existências absolutamente vinculadas ao território e que a conquista da terra de trabalho, enquanto lócus da produção dos meios de existência, consiste no principal objetivo de suas lutas (Martin \& Fernandes, 2004; Pedon, 2009; Torres, 2011). De acordo com essa definição, o Movimento dos Trabalhadores Rurais Sem Terra (MST) consiste em um movimento socioterritorial, sendo, na atualidade, um dos protagonistas na luta pela Reforma Agrária em todo o país (Fernandes, 2001; Oliveira, 2001).

De modo estratégico, movimentos como o MST realizam ocupações, principalmente, de terras que não cumprem a função social conforme determina o Artigo 186 da Constituição Federal, ao estabelecer que as propriedades rurais devem ser produtivas e, simultaneamente, atender aos seguintes requisitos: 
I - aproveitamento racional e adequado;

II - utilização adequada dos recursos naturais disponíveis e preservação do meio ambiente;

III - observância das disposições que regulam as relações de trabalho;

IV - exploração que favoreça o bem-estar dos proprietários e dos trabalhadores (Brasil, 1988).

As ocupações possibilitam o acesso à terra, sendo, paralelamente, a forma com que os trabalhadores sem-terra pressionam o governo e impõem a realização de uma política de assentamentos rurais (Fernandes, 2001). Assim como assevera Fernandes (2001), as ocupações decorrem da necessidade, são os trabalhadores desafiando o Estado e o capitalismo. Por isso, precisamos compreender essas ações como o início de uma experiência de transformação da realidade cuja finalidade é a de conquistar território para a criação e para a recriação do modo de vida camponês, caracterizado pelo cultivo da terra, pelo trabalho familiar, pela organização social comunitária e pelo vínculo com a natureza (Marques, 2008).

Em Barbosa Ferraz, existem duas ocupações de terra: o pré-assentamento Irmã Dorothy e o acampamento Nossa Senhora do Carmo. Adiante, abordaremos algumas considerações acerca desses territórios.

\section{A LUTA PELA TERRA EM BARBOSA FERRAZ: O PRÉ-ASSENTAMENTO IRMÃ DOROTHY E O ACAMPAMENTO NOSSA SENHORA DO CARMO}

A história do pré-assentamento Irmã Dorothy teve início no dia 22 de novembro de 2005, quando, aproximadamente, 50 famílias camponesas vinculadas ao MST ocuparam o total de 573,20 hectares, sendo 414,4 ha da Fazenda São Paulo e 158,8 ha do Sítio São Vicente, propriedades limítrofes pertencentes ao mesmo grupo familiar (Fig. 3).

Figura 3: Imagem de satélite da área do pré-assentamento Irmã Dorothy.

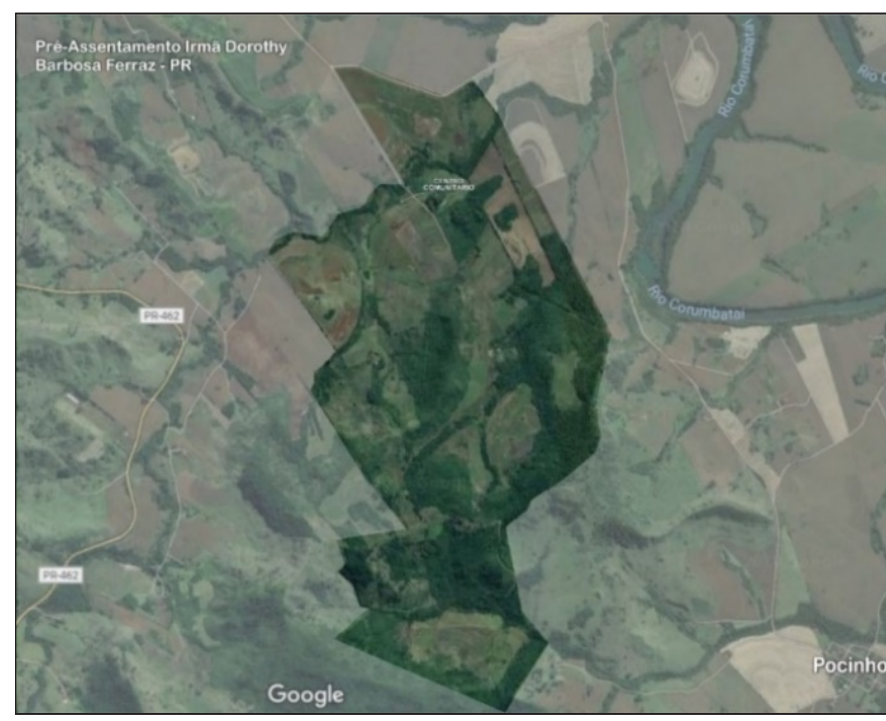

Fonte: elaborado a partir de Google Maps (2018). 
De acordo com os relatos dos trabalhadores, o que motivou a ocupação foram as denúncias de que o estabelecimento apresentava baixa utilização da terra, desmatamento de áreas de preservação ambiental e animais em situação precária que, em função da falta de vacinação e das doenças contraídas, ofereciam riscos às unidades produtivas vizinhas. Sobre essa situação, o camponês Enes de Lima Machado, 28 anos, conta-nos que, "quando nóis cheguemo aqui, encontramo a fazenda em situação de abandono, o gado cheio de doença, tava tudo mal zelado, bicho, criação morrendo, aqui era uma ameaça para a sociedade". No entendimento dos camponeses, esses problemas indicavam que a propriedade não tinha aproveitamento adequado, não utilizava corretamente os recursos naturais disponíveis e a exploração não favorecia o bem-estar, portanto, estava destoante do que a Constituição Federal exige e deveria tornar-se território de reforma agrária.

A partir do momento em que acessaram a terra, as famílias levantaram barracos de lona para moradia e separaram áreas para o plantio coletivo de alimentos e para a criação de animais. Esse momento representou a construção da territorialidade, ou seja, da forma de uso do território, marcada pelas significações culturais que fazem parte da organização espacial dos sem-terra. Conforme o grupo conseguiu estruturar-se, tornou-se possível ampliar e diversificar a produção e, assim, comercializar os excedentes das lavouras na região de Barbosa Ferraz. Quando questionamos os trabalhadores sobre a produtividade atual do pré-assentamento, eles destacam que, com o que plantam, quase não precisam consumir produtos dos supermercados da cidade, assim como afirma o camponês João Maria da Silva, 66 anos: "com o que nóis produz aqui, nóis compra muito pouco no mercado". Ainda segundo o Sr. João, entre os principais alimentos cultivados no pré-assentamento estão arroz, feijão, milho, mandioca, batata doce, abóbora, maracujá, banana, hortaliças e leite.

A partir da ocupação, que já completou 14 anos, os trabalhadores passaram a lutar judicialmente para conseguir a desapropriação e a transformação da área em assentamento. Para isso, utilizam relatórios e laudos técnicos elaborados por órgãos públicos que pontuam os problemas da propriedade antes da ocupação. Apesar de todos os esforços, no ano de 2008, o Poder Judiciário determinou a reintegração de posse para o proprietário e instituiu ordem de despejo para as famílias sem-terra. Nesse período, os camponeses foram alocados temporariamente em um terreno cedido pela Prefeitura de Barbosa Ferraz. Esse terreno era um aterro desativado, localizado a cerca de um quilômetro da propriedade em litígio. Ir para o local foi um pedido que os próprios trabalhadores fizeram ao poder público municipal, tendo em vista que o plano era permanecer nos arredores da propriedade e, assim que possível, tentar realizar a reocupação. Quinze dias após a realização do despejo, os camponeses organizaram o retorno para a área, contando com a ajuda de outras famílias ligadas ao MST, oriundas de acampamentos e assentamentos da região. Sobre esse episódio, a camponesa Lúcia Correa Richuiti, de 42 anos, nos conta que: "nóis tivemo quatro dias pra sair da área, nóis fomo pro lixão desativado da prefeitura, depois nóis vortemo de novo, depois de quinze dias, os companheiro do movimento nos ajudô e nóis vortô".

Desde a reocupação, os camponeses vivem sobre constantes ameaças de um novo despejo. Para driblar essas ameaças, eles constroem articulações e estratégias políticas, 
especialmente no sentindo de evidenciar que a sociedade local apoia a permanência das famílias no município, levando em conta as relações afetivas construídas e os impactos positivos que esses trabalhadores geram para a economia local, sobretudo, considerando que investem o dinheiro recebido pela negociação do excedente da produção no comércio da cidade. $\mathrm{O}$ apoio da sociedade aos camponeses é demonstrado por meio da participação de diversas entidades em reuniões e em manifestações e por meio da elaboração de declarações e abaixo-assinados, tal como o fragmento que apresentamos na Figura 4, em que os moradores pedem às autoridades que “... procedam as negociações necessárias para permanência destas famílias no local e encaminhem o assentamento definitivo".

Figura 4: Fragmento do abaixo-assinado em apoio às famílias do pré-assentamento Irmã Dorothy.

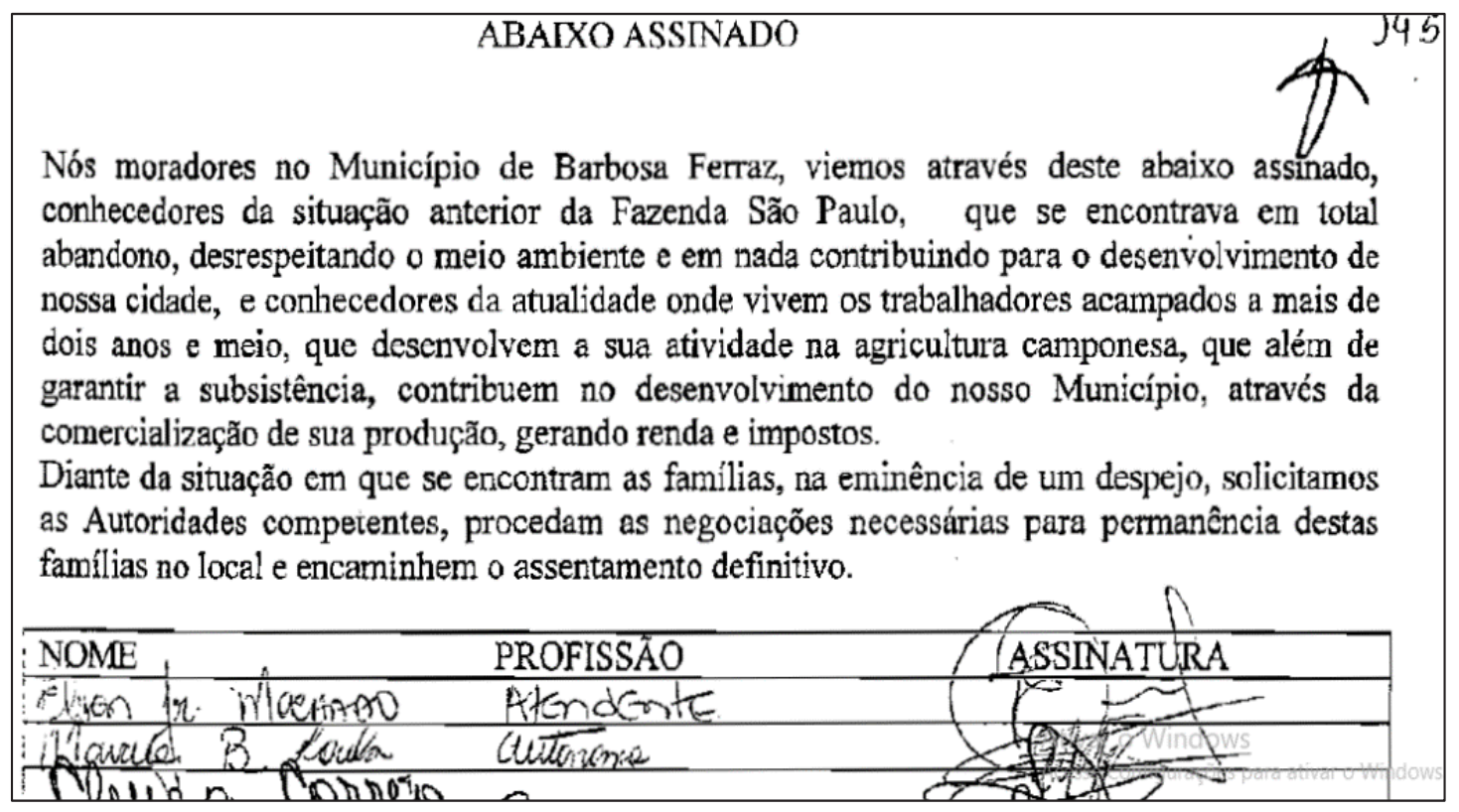

Fonte: autos do processo da Justiça Federal no. 5002649-24.2017.4.04.7010, documento elaborado em 2008.

Apesar das constantes ameaças de despejo, os trabalhadores procuram avançar no processo organizativo. No ano de 2013 elaboraram, por conta própria, o regimento interno, estabelecendo as regras para o funcionamento do pré-assentamento. Além disso, os camponeses realizaram a divisão da propriedade ocupada em lotes menores. O parcelamento da área acompanhou o projeto que em que foram demarcados 33 lotes, distribuídos por sorteio para as 33 famílias que, na ocasião, compunham o pré-assentamento (Fig. 5). 
Figura 5: Projeto de parcelamento da área ocupada - Irmã Dorothy ${ }^{4}$.

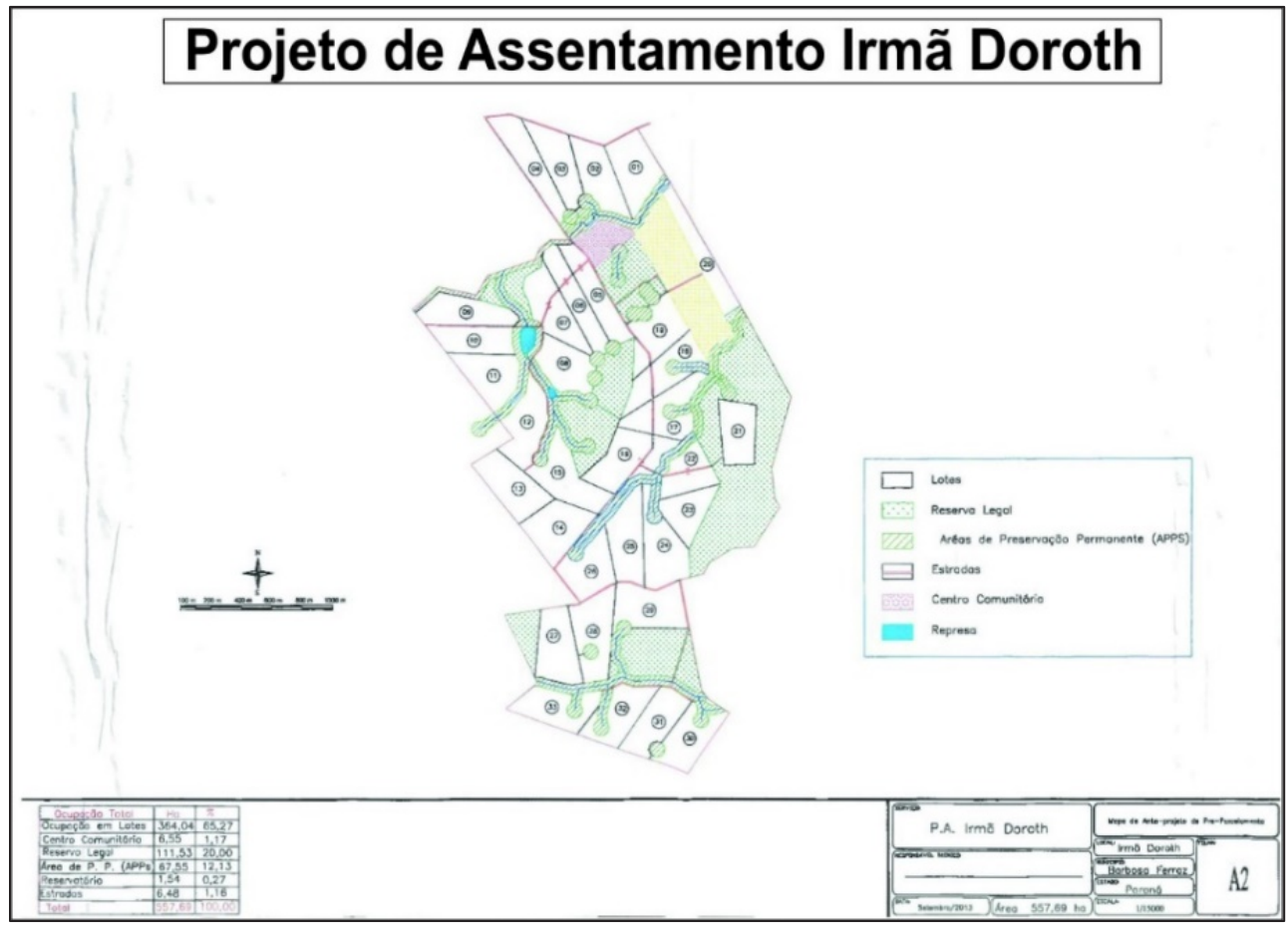

Fonte: acervo da camponesa Marcia Aparecida da Silva de Jesus.

Cada lote, com uma residência construída, possui em torno de 12 hectares, variando conforme a declividade do terreno. Nem todos os camponeses têm acesso ao curso d'água, assim aqueles que não são contemplados garantem o abastecimento por meio das fontes vizinhas por meio de redes de encanamento construídas individualmente. Além dos lotes, no projeto desenvolvido pelos camponeses, estão demarcadas as estradas e separadas as áreas de preservação permanente e as reservas legais. Também está representado o espaço comunitário, que corresponde à antiga casa sede da propriedade, onde as famílias realizam cerimônias religiosas, comemorações e assembleias.

Segundo a camponesa Marcia Aparecida da Silva de Jesus, 40 anos, a decisão de parcelar a área foi resultado do gradual aumento da produção e, principalmente, do número de animais: "O povo tava amontoado na sede e daí tava dando muito excesso de criação, vaca, porco, galinha, e daí se tinha muita reclamação, não tinha como segurar esses bichos juntos, chegaram num consenso nas reunião que tinha que organizar melhor, dar mais espaço para as famílias".

Com a elaboração do regimento interno e com o parcelamento, os camponeses passaram a considerar a área um pré-assentamento, designação utilizada para declarar que ainda não dispõem da conquista definitiva da terra como nos assentamentos, mas que já estão em um estágio de organização mais evoluído que o dos acampamentos, em que, normalmente, os trabalhadores permanecem reunidos em um ponto estratégico, com condições mais precárias de moradia, de trabalho, entre outros. É válido ressaltar que esse termo não é reconhecido pelo Poder Judiciário.

4 A área indicada em amarelo corresponde a uma propriedade que não faz parte da ocupação nem pertence ao mesmo proprietário. 
As ameaças de despejo sofridas pelos trabalhadores desde a reocupação se intensificaram a partir de julho de 2017, período em que foi realizada a última audiência de conciliação entre as partes na Comarca de Barbosa Ferraz. Nessa audiência, o proprietário propôs que as famílias deixassem a área voluntariamente e pacificamente até o dia $1^{\circ}$ de novembro do mesmo ano sem direito a colher as safras remanescentes. Como advertência, ficou estabelecido que, caso os camponeses não aceitassem a proposta, estariam expostos ao despejo, que poderia acontecer sem aviso prévio.

Em função da gravidade da questão, os trabalhadores requereram ao juiz responsável pelo caso o prazo de cinco dias úteis para encaminhar uma resposta a respeito da proposta realizada na audiência. O juiz concedeu o prazo solicitado e, ainda, decidiu que “... na falta de resposta, com o transcurso do prazo sem manifestação, deverá a ordem judicial, já não suspensa em sede recursal, ser cumprida imediatamente, inclusive com auxílio da força pública" (Fig. 6).

Figura 6: Decisão referente à audiência de conciliação realizada na Comarca de Barbosa Ferraz, PR.

\section{COMARCA DE BARBOSA FERRAZ VARA DA FAZENDA PÚBLICA}

Ao final $\circ \mathrm{MM}^{\circ}$. Juiz prolatou o seguinte despacho, do qual saíram intimados todos os presentes: 1. Acolho o pedido constante da "B" acima. 2. Via de consequência, concedo à parte requerida o prazo de 05 (cinco) dias úteis, na forma solicitada. 3. Consigno que na falta de resposta, com o transcurso do prazo sem manifestação, deverá a ordem judicial, já não suspensa em sede recursal, ser cumprida imediatamente, inclusive com o auxílio de força pública. 4. Os requeridos se comprometem a não plantar nada na propriedade invadida, e desde já saem cientes de que não terão direito a qualquer safra a ser colhida posteriormente à data de $01 / 11 / 2017$, em caso de aceitação da proposta de acordo formulada pelos autores. 5. Ultrapassado o prazo para manifestação dos requeridos, voltem imediatamente conclusos os autos. 6. O Ministério Público se compromete ainda a acompanhar, in loco, qualquer espécie de desocupação voluntária ou coercitiva a ser realizada nestes autos. 7. Que os invasores se comprometem quando da saída da propriedade, não depredarem o imóvel em especial a casa da sede.

Fonte: autos do processo da Justiça Federal nº 5002649-24.2017.4.04.7010, documento elaborado em 2017.

Ao reunir-se para discutir e para elaborar a resposta, os camponeses decidiram aceitar a desapropriação voluntária desde que o Instituto Nacional de Colonização e Reforma Agrária (INCRA) se responsabilizasse por realizar: a) a abertura do edital de compra, de aquisição de terras na região Centro-Norte do Paraná, ainda no corrente mês de agosto; b) o pagamento das despesas de deslocamento das famílias do pré-assentamento Irmã Dorothy para eventual área ofertada ou outro local escolhido pelas famílias; c) a indenização das famílias pelo investimento realizado no preparo da produção para a safra.

A Justiça Estadual julgou improcedente a contraproposta realizada pelos camponeses e intimou os trabalhadores a deixarem a área até o dia $1^{\circ}$ de novembro de 2017, determinando que, caso o prazo fosse transcorrido e a ordem não fosse atendida, a força policial seria requisitada para a realização da desocupação. 
Desde então, os camponeses tem passado por períodos de bastante tensão. Para tentar evitar que um novo despejo aconteça, os trabalhadores atuam politicamente via coordenação estadual do MST. Entre as ações efetuadas, o grupo recorre às autoridades do poder público regional, às lideranças religiosas, às organizações sindicais, entre outras, para que essas instituições intercedam junto ao Estado a fim de que a decisão do judiciário não seja cumprida pelo Poder Executivo. A manifestação desses diversos segmentos da sociedade é importante no sentindo de mostrar que existe apelo a favor das famílias pré-assentadas e que a realização de um despejo poderia gerar uma situação de instabilidade e de conflito, desdobrando-se em uma repercussão negativa.

Quando questionados sobre o que fazer caso um novo despejo seja realizado, os trabalhadores declaram que pretendem reocupar a propriedade. Segundo os relatos, essa posição deriva do fato de que considerável parcela do grupo não conseguiria inserir-se no mercado de trabalho urbano, considerando que muitos dos trabalhadores possuem baixa escolaridade e já apresentam idade avançada. Por esse motivo, para essas famílias, desafiar as ordens de reintegração de posse e manter a ocupação significa, principalmente, lutar pelas condições de sobrevivência.

O segundo conflito rural localizado em Barbosa Ferraz é o acampamento Nossa Senhora do Carmo, cuja história teve início no dia 16 de julho de 2006 (Fig. 7), quando, aproximadamente, 15 famílias oriundas da região de Campo Mourão e vinculadas ao MST ocuparam os 80 hectares da fazenda denominada Os Oitenta (Andrade, 2013).

Figura 7: Acampamento Nossa Senhora do Carmo no ano de 2006.

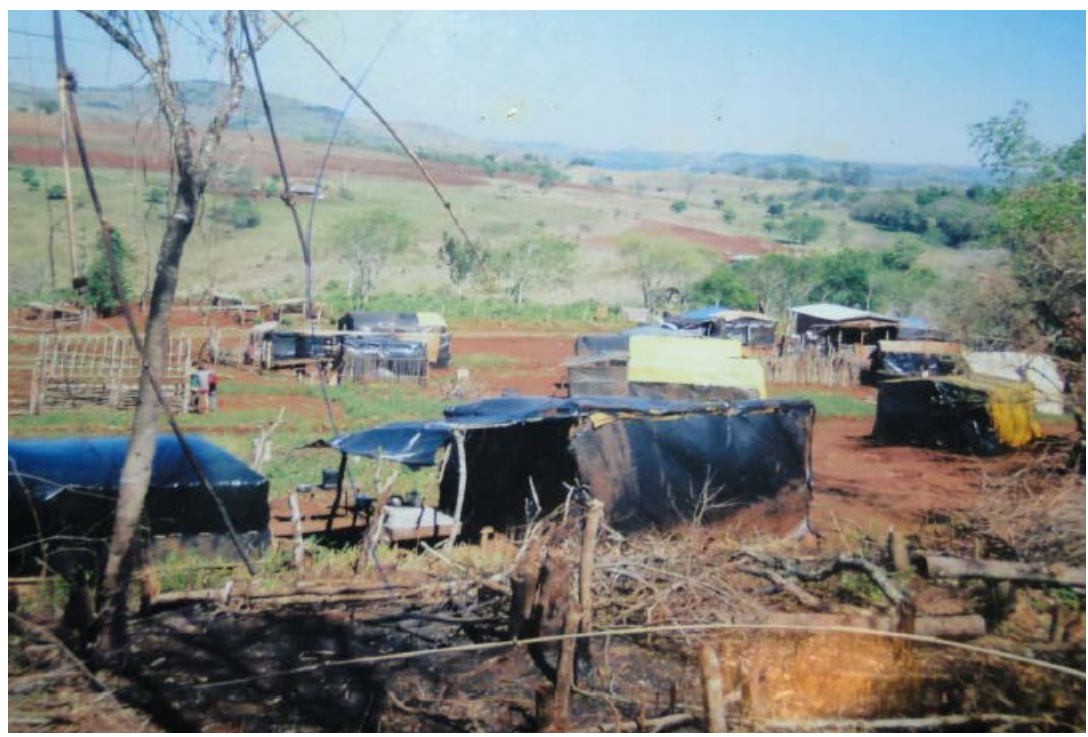

Fonte: Andrade (2013)

Conforme as informações cedidas pelos trabalhadores, a área ocupada faz parte de uma fazenda localizada na divisa do município de Iretama com Barbosa Ferraz. A parte da fazenda pertencente à Iretama foi cedida para a reforma agrária, dando origem ao assentamento Muquilão. Entretanto, por não possuir escritura, a porção de terra inserida 
em Barbosa Ferraz ficou fora do projeto de assentamento, estimulando os camponeses a ocuparem essa fração de território.

De acordo com Andrade (2013), as famílias do acampamento Nossa Senhora do Carmo enfrentam problemas semelhantes aos dos trabalhadores do pré-assentamento Irmã Dorothy, tanto no sentido de conquistar definitivamente a terra, como no de criar as condições necessárias para a manutenção das necessidades básicas.

Dessa forma, enquanto lutam judicialmente para transformar a ocupação em assentamento, os camponeses produzem, em um espaço individual, cereais como milho, feijão e arroz e criam caprinos, suínos e equinos em pastagens de uso coletivo. Satisfeitas as necessidades de consumo, o excedente da produção é comercializado nos municípios de Iretama e de Barbosa Ferraz (Andrade, 2013).

Além de lidar com a lentidão do processo de reforma agrária e com as dificuldades para produzir alimentos decorrentes da falta de recursos financeiros para investimentos, esses trabalhadores passam por diversas privações, tais como falta de moradias adequadas, saneamento básico, acesso à energia elétrica, entre outros. A somatória dessas condições fez com que, ao longo do percurso, muitas famílias desistissem da ocupação, partindo em direção a outros acampamentos, ou ainda buscando alternativas de vida fora do campo. Por esse motivo, no ano de 2013, constatou-se que, das 15 famílias que iniciaram o processo de territorialização, restavam apenas seis (Andrade, 2013).

Os camponeses de ambas as ocupações afirmam que, em função do processo eleitoral de 2018, tiveram suas expectativas reduzidas no que tange à transformação das áreas em assentamentos. Além disso, sentem-se mais ameaçados do que antes com relação à realização de despejos e ao uso da violência como forma de reprimir a luta pela terra. $\mathrm{O}$ principal motivo para o aumento da insegurança foi a vitória de Jair Messias Bolsonaro para a Presidência da República, que possui uma postura política notoriamente contrária à reforma agrária. Durante a campanha eleitoral declarou que as ações do MST deveriam ser tipificadas como "terroristas" e incentivou, diversas vezes, que ruralistas e latifundiários usassem armas de fogo contra as ocupações (De Olho nos Ruralistas, ed. 23/10/2018).

Após eleito, uma das primeiras ações do governo Bolsonaro foi a criação da Secretaria Especial de Assuntos Fundiários, cuja chefia foi entregue a Luiz Antônio Nabhan Garcia, ex-presidente da União Democrática Ruralista (UDR), organização conhecida pela defesa dos interesses dos latifundiários. A escolha de um líder ruralista para o comando da secretaria denota de que maneira o governo Bolsonaro pretende tratar a Reforma Agrária no país, sobretudo, considerando a importância desse órgão que, entre suas atribuições, abrange a formulação, a normatização e a supervisão de políticas de colonização e de reforma agrária; a identificação, a delimitação, a demarcação e o registro de terras ocupadas tradicionalmente por povos indígenas; a regularização fundiária de áreas decorrentes de reforma agrária ${ }^{5}$.

5 Para mais detalhes sobre as competências da Secretaria Especial de Assuntos Fundiários, ver o Art. 11 do Decreto 9.667, de janeiro de 2019. 
A nível estadual, os camponeses enfrentam a falta de abertura para negociações e os ataques às ocupações do governador eleito Carlos Roberto Massa Júnior, que em 2019 (primeiro ano de governo), realizou nove reintegrações de posse no Paraná, resultando o despejo de 561 famílias em todo o estado, 361 a mais que em 2018, segundo dados da Comissão Pastoral da Terra ([CPT] 2018; 2019). Várias das ações executadas em 2019 foram marcadas pela violência da Polícia Militar contra os camponeses sem-terra, como exemplifica a notícia publicada pela Rede Brasil Atual (ed. 03/12/2019). A série de despejos efetuados gerou tensão nas famílias de Barbosa Ferraz, pois sabiam que as áreas ocupadas poderiam ser alvos da ação do Estado a qualquer momento. Em algumas situações, os trabalhadores organizaram-se internamente, no sentido de oferecer resistência caso a polícia se deslocasse para cumprir a ordem de reintegração de posse.

A situação das ocupações que abordamos nesse trabalho evidencia que a falta de implementação de uma política de reforma agrária ampla e irrestrita faz com que os conflitos rurais não sejam de fato resolvidos, perdurando até que, em razão das dificuldades, os camponeses desistam da luta, ou, ainda, até que o Estado intervenha e, em conivência com os interesses dos proprietários, realize as reintegrações de posse. Essas ações apenas empurram o problema social, uma vez que a estrutura fundiária não é corrigida e o acesso à terra e às políticas públicas não é garantido para o conjunto dos camponeses sem-terra, marcado por uma trajetória de desterritorialização.

Nessa perspectiva, o contexto vivenciado pelas famílias do pré-assentamento Irmã Dorothy e do Acampamento Nosso Senhora do Carmo serve-nos de amostra da realidade e dos desafios da luta pela terra enfrentados por milhares de famílias acampadas em todo o estado.

\section{CONSIDERAÇÕES FINAIS}

Com base no exposto, é possível compreendermos que os conflitos rurais existentes na atualidade são fruto de um processo histórico de exclusão e de desterritorialização, intensificado a partir da modernização agrícola, que significou a expansão do capitalismo no campo. Em Barbosa Ferraz notamos que, além de transformar o modo de produção, a modernização resultou, principalmente em sua fase de consolidação, na absorção dos pequenos estabelecimentos pelas médias e grandes unidades produtivas, modificando o modelo fundiário estabelecido pela colonização e restringindo o acesso à terra para aqueles que possuíam pouco capital.

Para a parcela dos trabalhadores que, em função desse processo, foram desterritorializados do campo, juntar-se aos movimentos socioterritoriais e construir estratégias de contestação à ordem dominante foi uma reação necessária. Isso, sobretudo, considerando a inoperância no Estado com relação à implantação de uma política de reforma agrária ampla e irrestrita que possibilite a reterritorialização e a reprodução do modo de vida camponês, viabilizando a construção de um modo de desenvolvimento alternativo ao capitalista hegemônico. 
Se a reforma agrária, no molde discutido e defendido pelos movimentos socioterritoriais, não acontece como deveria, isto é, mediante a ação dos governos, os trabalhadores sem-terra impõem que, ao menos, seja realizada uma política de assentamento, usando as ocupações e a resistência às ordens de despejo como instrumento para exercer poder e para disputar territórios. Nesse sentido, os assentamentos têm sido as maiores conquistas da luta pela terra e inauguram uma nova fase da vida dos camponeses, marcada por desafios ligados, principalmente, à manutenção do território e dos direitos adquiridos.

Tanto o acampamento Nossa Senhora do Carmo como o pré-assentamento Irmã Dorothy apresentam trajetórias ainda sem um desfecho. Na atualidade, as maiores preocupações desses trabalhadores são a repressão e a violência que a luta pela terra tende a apresentar, considerando até o momento, a existência na esfera federal do declarado comprometimento do governo com os ruralistas e os latifundiários em desfavor dos movimentos socioterritoriais e dos camponeses sem-terra. Já na esfera estadual, percebemos que ações estão alinhadas com o discurso do Presidente Bolsonaro, sobretudo, considerando a quantidade de despejos realizados em 2019 e a intensificação do uso da força policial.

\section{AGRADECIMENTOS}

À Coordenação de Aperfeiçoamento de Pessoal de Nível Superior (CAPES), pelo fornecimento de bolsa de estudos à primeira autora.

\section{REFERÊNCIAS}

Andrade, A.A.V. (2013). Poder, estado e capital nos processos des-re-territorialização no campo na microrregião geográfica de Campo Mourão-PR. Tese de doutorado, Universidade Estadual de Maringá, Maringá, PR, Brasil. Disponível: http://www.pge.uem.br/documentos-para-publicacao/teses/teses-2013 pdfs/ AureaAndradeViana\%20Andrade.pdf

Cancian, N.A. (1981). Cafeicultura paranaense - 1900/1970. Curitiba: Grafipar.

Constituição da República Federativa do Brasil de 1988. Recuperado de http:/ / www.planalto.gov.br/ccivil_03/ constituicao/constituicaocompilado.htm

Comissão Pastoral da Terra. Violência contra a ocupação e a posse 2018. Recuperado de https://www. cptnacional.org.br/component/jdownloads/send/13-violencia-contra-a-ocupacao-e-a-posse/14147violencia-contra-a-ocupacao-e-a-posse-2018? Itemid=0

Comissão Pastoral da Terra. Violência contra a ocupação e a posse 2019. Recuperado de https://www. cptnacional.org.br/component/jdownloads/send/13-violencia-contra-a-ocupacao-e-a-posse/14175violencia-contra-a-ocupacao-e-a-posse-2019?Itemid $=0$

De Olho nos Ruralistas. (2018, outubro 23). Bolsonaro promete tipificar sem-terra como terrorista; Haddad quer combater impunidade no campo. Recuperado de https:/ / deolhonosruralistas.com.br/2018/10/23/bolsonaropromete-tipificar-sem-terra-como-terroristas-haddad-quer-combater-impunidade-no-campo/

Decreto n.9667, de 02 de janeiro de 2020. A prova a estrutura regimental e o quadro demonstrativo dos cargos em comissão e das funções de confiança do Ministério da Agricultura, Pecuária e Abastecimento. Recuperado de https://www.in.gov.br/materia/-/asset_publisher/Kujrw0TZC2Mb/content/id/57633308 
Fernandes, B.M. (2001). A formação do MST no Brasil. 2a ed. Petrópolis: Vozes. (Obra original publicada em 2000).

Fernandes, B.M. (2008). Entrando no território dos territórios. In: E.T. Paulino \& J E. Fabrini (Orgs.). Campesinato e território em disputa (pp. 237-302). São Paulo: Expressão Popular.

Haesbaert, R. (2011). O mito da desterritorialização: do "fim dos territórios" à multiterritorialidade. 6a ed. Rio de Janeiro: Bertrand Brasil. (Obra original publicada em 2004).

Instituto Brasileiro de Geografia e Estatística. (1970, 1980, 1991, 2000, 2010). Censo Demográfico. Recuperado de https://sidra.ibge.gov.br/Tabela/200

Instituto Brasileiro de Geografia e Estatística. (1970). Censo Agropecuário Paraná 1970. Rio de Janeiro: IBGE. Instituto Brasileiro de Geografia e Estatística. (1980). Censo Agropecuário Paraná 1980. Rio de Janeiro: IBGE. Instituto Brasileiro de Geografia e Estatística. (1996). Censo Agropecuário Paraná 1996. Recuperado de https://downloads.ibge.gov.br/downloads_estatisticas.htm

Instituto Brasileiro de Geografia e Estatística. (2006). Censo Agropecuário 2009. Recuperado de https:/ / sidra. ibge.gov.br/tabela/2727

Instituto Brasileiro de Geografia e Estatística. (2017). Censo Agropecuário 2017. Recuperado de https:/ / sidra. ibge.gov.br/tabela/6710\#resultado

Instituto Nacional de Colonização e Reforma Agrária. Classificação dos imóveis rurais. Recuperado de http:/ / www.incra.gov.br/pt/modulo-fiscal.html

Luciani, A.C., \& Colavite, A.P. (2014). A paisagem rural: um estudo de caso em Barbosa Ferraz - PR. Revista Geomae, 5(1,2):42-60.

Marques, M.I.M. (2008). Agricultura e campesinato no mundo e no Brasil: um renovado desafio à reflexão teórica. In E.T. Paulino \& J.E. Fabrini (Orgs.). Campesinato e território em disputa (pp. 49-79). São Paulo: Expressão Popular.

Martin, J.Y., \& Fernandes, B.M. (2004). Movimento socioterritorial e "globalização": algumas reflexões a partir do caso do MST. Lutas Sociais (PUC-SP), 12:1-12.

Martins, J.S. (1981). Os camponeses e a política no Brasil: as lutas sociais no campo e seu lugar no processo político. Petrópolis: Vozes.

Oliveira, A.U. (2001). Agricultura camponesa no Brasil. 4a ed. São Paulo: Contexto. (Obra original publicada em 1947).

Pedon, N.R. (2009). Movimentos socioterritoriais: uma contribuição conceitual à Pesquisa Geográfica. Tese de doutorado, Universidade Estadual Paulista, Faculdade de Ciência e Tecnologia, Presidente Prudente, SP, Brasil. Recuperado de http://www2.fct.unesp.br/nera/ltd/tese_pedon.pdf

Raffestin, C. (1993). Por uma geografia do poder. São Paulo: Ática.

Rede Brasil Atual. (2019, dezembro 03). PM realiza ação violenta contra 50 famílias em acampamento do MST no Paraná. Recuperado de https://www.redebrasilatual.com.br/cidadania/2019/12/pm-realiza-acaoviolenta-contra-50-familias-em-acampamento-do-mst-no-parana/

Saquet, M.A. (2007). Abordagens e concepções de território. São Paulo: Expressão Popular.

Serra, E. (1992). Os Primeiros Processos de Ocupação da Terra e a Organização Pioneira do Espaço Agrário do Paraná. Boletim de Geografia, 10(1): 61-93.

Serra, E. (2009). Colonização, uso da terra e conflitos rurais no Paraná. Anais do Encuentro de Geógrafos de América Latina, Montevidéu, Uruguai, 12, pp. 1-26.

Silva, J.G. (1981). A modernização dolorosa. Rio de Janeiro: Zahar Editores.

Silva, J.G. (1985). O que é questão agrária. 11a ed. São Paulo: Brasiliense. (Obra original publicada em 1980).

Stédile, J.P., Fernandes, B.M. (2012). Brava gente: a trajetória do MST e a luta pela terra no brasil. 2a ed. São Paulo: Expressão Popular. (Obra original publicada em 1999). 
Torres, F. (2011). Territorio y lugar: potencialidades para el análisis de la constitución de sujetos políticos. El caso de un movimiento de desocupados en Argentina. Geograficando: Revista de estudios geográficos, 7(7):1-30.

Yokoo, E.N. (2013). A dinâmica das frentes de ocupação territorial na Mesorregião Centro-Ocidental paranaense. Tese de doutorado, Universidade Estadual de Maringá, UEM, Maringá, PR, Brasil. Recuperado de file:///D:/Downloads/000213163.pdf

Data de submissão: 12/nov./2019

Data de aceite: 24/out./2020 